\title{
Impacts of management on leaching of nitrate from pastures
}

\author{
J.L. BROCK, P.R. BALL, and R.A. CARRAN \\ $D S I R$ G rasslands, Private Bag, Palmerston North
}

\begin{abstract}
Clover-based grasslands as used in New Zealand, while considered "clean" relative to grasslands farmed intensively with fertiliser nitrogen $(\mathrm{N})$, are nevertheless polluting. Recent measurements of nitrate- $\mathrm{N}$ down the soil profile below heavily stocked $(22.5$ ee/ha $)$ pastures grazed by sheep, have shown that leaching losses under set stocking are 2-3 times those from rotational grazing (37 vs $16 \mathrm{~kg}$ $\mathrm{N} / \mathrm{ha} / \mathrm{yr}$ ). As the input of $\mathrm{N}$, its storage, and outgoings in animal products are similar in both systems, this indicates that considerably more urinary $\mathrm{N}$ is being lost to the aerial environment from rotationally grazed pastures, with nitrate leaching being the main avenue of loss under set stocking. Differences in sward structure are suggested as the major factor. Lower nitrate leaching from cocksfoot vs ryegrass-based pastures are thought to be associated with lower herbage quality factors reducing urinary $\mathrm{N}$ formation. While grazing management will not greatly influence total $\mathrm{N}$ losses to the environment, it can influence the avenues by which $\mathrm{N}$ enters the wider environment. Aquatically sensitive catchments may be better protected from leaching of nitrate by modification of the grazing management approaches.
\end{abstract}

Keywords pasture management, nitrate leaching, ammonia volatilisation, pasture structure, herbage quality, groundwater pollution

\section{Introduction}

There is general demand for better accountability of the environmental impacts of agricultural practices. Pollution affects the quality of life for people world wide, and water quality is becoming of major concern in many countries as population growth and improved living standards place greater demands on potable water. Nitrate pollution has been identified as one problem. Nitrate moves with the ground water into deeper aquifers, as a result of years of intensive farming, especially where fertiliser nitrogen $(\mathrm{N})$ has been used. Clover-based pastures, as used in New Zealand for animal production, are seen as environmentally "clean", although they still have relatively large inherent $\mathrm{N}$ losses due to the grazing animal, and are therefore polluting (Field \& Ball 1982), if to a lesser degree.

\section{Pathways of $\mathrm{N}$ losses}

Nitrogen losses from grazed pastures are driven primarily by the grazing animal. Most of the $\mathrm{N}$ ingested during grazing is excreted on to small areas in urine patches, at concentrations approaching the annual requirements of pasture $(30-60 \mathrm{~g} \mathrm{~N} / \mathrm{m}$,), far in excess of the sward's capacity for uptake in the short term. The major part of this $\mathrm{N}$ is open to loss through two main pathways. First, hydrolysis of urea to ammonia occurs rapidly, and under appropriate environmental conditions (summer-autumn) some of the ammonia formed is readily volatilised into the atmosphere. There is evidence that some of this ammonia can be re-absorbed by herbage, thereby reducing losses (Denmead et al. 1976). Second, after nitrification of ammonuim to nitrate, any excess nitrate in the urine patch is open to leaching below the root uptake zone. Thereafter, nitrate moves into the ground water when drainage. occurs. (winter-). Both pathways operate in pastures, with the emphasis changing seasonally.

\section{Can $\mathrm{N}$ losses by manipulated?}

There appears to be little scope to change the total amount of $\mathrm{N}$ lost short of changing stocking rate (Field \& Ball 1982), but the seasonality of the two main pathways of loss would suggest that manipulation of pasture management may be able to influence the balance between them.

To this end, the nitrate-N profile below a long term grazing management experiment was studied to see what influence differences in defoliation patterns may have had on the quantity of nitrate escaping in drainage beneath the pastures.

\section{Experimental design and sampling}

The experiment involved small, self-contained farmlets to compare 3 systems of grazing: (1) rotationally grazed (RG) all year with $10-12$ grazings/year at rotations lengths varying from 24 days in spring to $\mathbf{6 0 +}$ in winter; (2) set stocked (SS) all year; and (3) a combination (CC) of rotational grazing, with a period of set stocking from lambing in late August to weaning in early January; and 2 
pasture types: (1) ryegrass-based plus clover, and (2) ryegrass and cocksfoot base plus clover. The common stocking rate was 22.5 ee/ha. During the lo-year duration of this experiment (sown and established in 1978-79), many aspects of sward performance (production, structure and symbiotic $\mathrm{N}$ fixation) and changes in soil chemical properties (total N, C, P, organic matter, soil microbial biomass $\mathrm{N}$ and $\mathrm{C}$, mineral $\mathrm{N}$ ) were monitored.

In spring 1989 (26-27 October) the soil beneath each pasture was measured, using a Giddings hydraulic drill to extract $68 \mathrm{~mm}$ diameter cores to 2.1 $\mathrm{m}$ depth. Each core was divided into $300-\mathrm{mm}$ sections and the top section divided again into two 150-mm sections, giving 8 sections in total. Each section was subsampled and deep frozen for later analysis for nitrate-N, which was extracted by shaking subsamples for 1 hour in $2 \mathrm{~N}$ KCI. Two cores were taken from each RG pasture, and one from each SS and CG pasture. There were 4 replications, making a total of 32 cores.

\section{Management effects}

Drainage down the soil profile, which leaches nitrate$\mathrm{N}$, occurs in specific events whenever rainfall significantly exceeds evapotranspiration. Rainfall records for the 2 years before sampling indicate that drainage would have occurred during the October of sampling $(35 \mathrm{~mm})$, and would have moved the wetting front to a depth of $200-250 \mathrm{~mm}$, and also in winter (May to July) when some $180 \mathrm{~mm}$ of drainage would have moved nitrate accumulated in the topsoil over summer-autumn to a depth of $1600-1800 \mathrm{~mm}$. These events are evident in profiles in Figures 1 and $\mathbf{2 b}$, the first causing the high value in the $150-300 \mathrm{~mm}$ section, which is still in the zone of active uptake, and the second in the high values between 900 and $1800 \mathrm{~mm}$, particularly in the RG and SS pastures (Figure 1). Most of the profile sampled represents drainage for one year only, as the heavy drainage $(480 \mathrm{~mm})$ of the previous year (May to September) would have effectively removed the previous year's nitrate from the profile measured.
Figure 1 clearly shows that the nitrate-N concentrations in the soil solution under the pastures to $2.1 \mathrm{~m}$ was 2.5 times higher for $\mathrm{SS}$ than $\mathbf{R G}$ and $\mathrm{CG}$ $(P<0.001)$. Calculations of the annual loss of nitrate below the uptake zone (300 to $1600-1800 \mathrm{~mm}$ ) were of a similar pattern ( $\mathbf{S S}=\mathbf{3 7}, \mathbf{R G}=17, \mathbf{C G}=16 \mathrm{~kg}$ $\mathrm{N} / \mathrm{ha} / \mathrm{yr}$ ), although the values are considerably less than the $60-80 \mathrm{~kg} \mathrm{~N} / \mathrm{ha} / \mathrm{yr}$ reported by Field et al. (1985) for a rotationally sheep grazed pasture on an adjacent site.

As the same stocking rate was used on all treatments, equal quantities of herbage utilisation (11.5 t DM/ha/yr) and return of $\mathrm{N}$ in excreta (460 $\mathrm{kg} / \mathrm{ha}$ less $40 \mathrm{~kg} \mathrm{~N} / \mathrm{ha}$ lost in animal products $=420$ $\mathrm{kg} \mathrm{N} / \mathrm{ha} / \mathrm{yr}$ ) would occur. Nitrogen fixation measurements showed similar inputs $(\mathrm{RG}=88$; $\mathrm{SS}=70 ; \mathrm{CG}=72 \mathrm{~kg} \mathrm{~N} / \mathrm{ha} / \mathrm{yr}$ ), as did changes in soil total $\mathrm{N}$ over the 10 years $(\mathrm{RG}+0.042 \%$; $\mathrm{SS}+0.041 \%$; $\mathrm{CG}+0.044 \% \mathrm{~N})$. Consideration of the partial mass balance (Ball 1982) would indicate that total $\mathrm{N}$ losses woul also be similar, in which case the losses of ammonia to the atmosphere must have been higher in RG and CG to offset the greater leaching under SS.

Differences in pasture structures may offer an explanation (Table 1). With the rapid removal of the herbage canopy, the high proportion of exposed bare soil (Hay et al. 1989) developed higher soil temperatures in the RG system, providing ideal conditions for ammonia volatilisation. High rates of ammonia volatilisation have been measured in warm dry summer-autumn conditions under rotational grazing at Palmerston North (Ball \& Ryden 1984), which suggest there would be a large proportion of $\mathrm{N}$ losses under RG from this source. By contrast, the substantial cover provided by the high density greater biomass SS pasture, could act as an absorbing surface for ammonia, and reduce maximum soil surface temperatures (by $6^{\circ} \mathrm{C}$, Table 1). Mitchell (1957) also reported a $15{ }^{\circ} \mathrm{C}$ differential between open RG swards and short dense swards. It seems that SS swards reduced ammonia volatilisation, retaining a higher proportion of the urinary $\mathrm{N}$ in the soil-plant system, and that the excess not absorbed by the
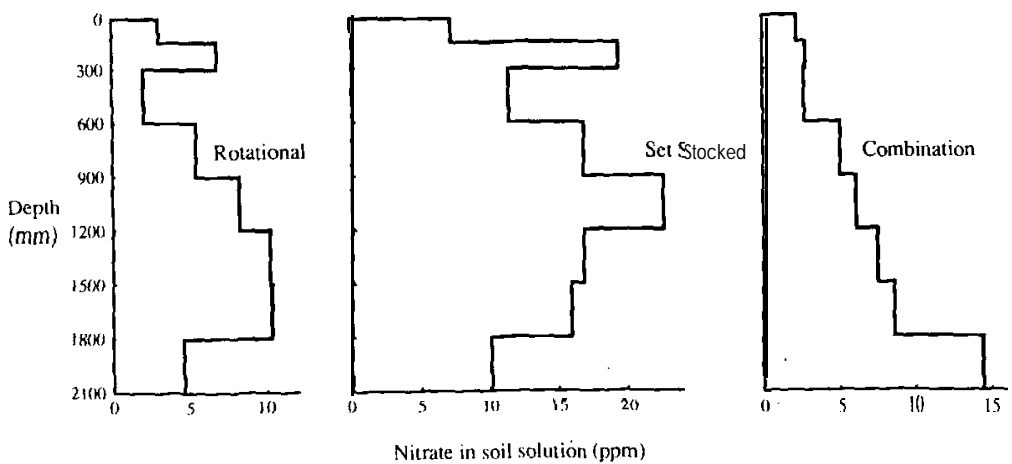

Figure 1 Soil nitrate profile below pastures grazed by sheep either rotationally, set stocked, or a combination of both. 
Table 1 Differences in mean annual pasture characteristics and soil surface temperatures in autumn, induced by defoliation management.

\begin{tabular}{|c|c|c|c|}
\hline & $\begin{array}{c}\text { Rotational } \\
\text { grazing }\end{array}$ & $\begin{array}{c}\text { Set } \\
\text { stocking }\end{array}$ & $\begin{array}{c}\text { Combination } \\
\text { grazing }\end{array}$ \\
\hline Residual grass biomass (kg/ha) & $1885 \mathrm{c}^{*}$ & $3520 \mathrm{a}$ & $2680 \mathrm{~b}$ \\
\hline Residual clover biomass (kg/ha) & $460 \mathrm{a}$ & $260 \mathrm{c}$ & $330 \mathrm{~b}$ \\
\hline Ryegrass tiller density $\left(\mathrm{m}^{2}\right)$ & $5300 \mathrm{C}$ & $10940 \mathrm{a}$ & $8270 b$ \\
\hline Clover growing points $\left(\mathbf{m}^{2}\right)$ & $3170 \mathrm{a}$ & $1830 \mathrm{~b}$ & $2310 b$ \\
\hline Bare ground $(\%)$ & $19 a$ & lc & $6 b$ \\
\hline Peak soil surface temperatures $(1$ March $){ }^{\circ} \mathrm{C}$ & 48 & 42 & 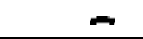 \\
\hline
\end{tabular}

* Values followed by different letters are significantly different at the $\mathbf{P}<0.05$ level (applies to Table 2).

Table 2 Effect of grazing management on mean soil properties.

\begin{tabular}{|c|c|c|c|}
\hline & $\begin{array}{c}\text { Rotational } \\
\text { grazing }\end{array}$ & $\begin{array}{c}\text { Set } \\
\text { stocking }\end{array}$ & $\begin{array}{c}\text { Combination } \\
\text { grazing }\end{array}$ \\
\hline Microbial biomass $\mathrm{N}$ (ppm dry soil), $0-7.5 \mathrm{~cm}$ & $97.2 \mathrm{~b}$ & $110,6 a$ & $111,1 a$ \\
\hline Microbial biomass $\mathrm{C}(\mu \mathrm{g} / \mathrm{g}$ dry soil $), 0-7.5 \mathrm{~cm}$ & $747 b$ & $843 a$ & $899 a$ \\
\hline Total soil organic matter $(\%), 0-15 \mathrm{~cm}$ & $7.24 \mathrm{c}$ & $7.68 \mathrm{~b}$ & $8.07 \mathrm{a}$ \\
\hline Soil organic matter light fraction $(\mathbf{0}), 0-7.5 \mathrm{~cm}$ & $0.131 \mathrm{c}$ & $0.169 \mathrm{a}$ & $0.146 b$ \\
\hline
\end{tabular}

plants was converted to nitrate, particularly in summer-autumn when plant growth may be restricted by water shortage, and was lost in subsequent drainage events.

Mean populations of soil organisms (Carran 1983) and soil organic matter content (Table 2) were higher in $\mathrm{SS}$ and $\mathrm{CG}$, suggesting a greater potential to immobilise $\mathrm{N}$ than in $\mathrm{RG}$. However the relative effect of these factors in the high $\mathrm{N}$ loading of the urine patch is not known, but would appear to be small and have little relation to mineral-N losses. The importance of these factors needs further detailed assessment.

The nature of the nitrate profile for CG would indicate that ammonia volatilisation from the predominantly rotational grazing period of the system was the major influence. Any effect of set stocking in spring was of little consequence, probably because most of any nitrate formed was taken up during this period of rapid growth, and that drainage events did not occur during the previous spring.
During the summer-autumn period when ammonia volatilisation is at its peak, the CG management is under rotational grazing. Most of the losses for any management system occur as a result of accumulation of summer-autumn surpluses of nitrate, with management determining only the extent of loss (Ball et al. 1985).

\section{Pasture species}

Under SS, cocksfoot did not persist and the pasture became ryegrass dominant within the first year. As a result the nitrate for both pasture types was similar (Figure 2a). Under rotational grazing, cocksfoot maintained a strong contribution to production (RG 57\%, CG $34 \%$ ) and th e nitrate 1 o s s w a s approximately half that of ryegrass-based pastures (cocksfoot $13 \mathrm{~kg} \mathrm{~N} / \mathrm{ha}$, ryegrass $27 \mathrm{~kg} \mathrm{~N} / \mathrm{ha}$ ) $(\mathrm{P}<0.01)$.

Several factors could be operating involving the quality of organic matter being produced from root
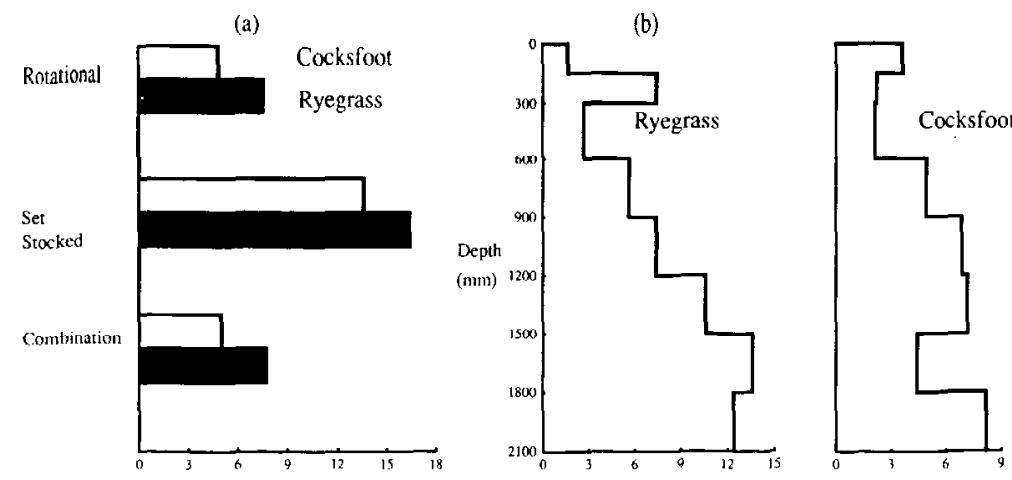

Nitratein soil solution(ppm)

Figure 2 The effect of pasture species mixtures on soil nitrate leaching: (a) for all grazing managements (b) on the nitrate profile for the rotationally grazed managements ( $\mathrm{RG}$ and $\mathrm{CG}$ ). 
and shoot residues, and the quantity of urinary- $\mathrm{N}$ cycling. Cocksfoot root material has been shown to be of lower quality (low $\mathrm{N}$, high $\mathrm{CN}$ rates) than ryegrass (Whitehead 1970), and if the same is true of shoot residues, then the immobilisation potential of the organic matter produced would be higher (and mineralisation potential lower) under cocksfoot pastures than ryegrass. This is supported in principle by the small but consistently lower soil nitrate levels found in the top $75 \mathrm{~mm}$ of soil under cocksfoot pastures over several years (5.6 cf $4.2 \mathrm{ppm}$ for ryegrass and cocksfoot respectively, $\mathbf{P}<0.001$ ), similar to the difference shown in the top $300 \mathrm{~mm}$ of the leaching profile (Figure 2b). However, further work is required on these quality aspects

\section{Implications}

The implications of this study are that while the form of grazing management may not greatly influence total losses of $\mathrm{N}$ to the environment, it can influence the avenue by which $\mathrm{N}$ enters the wider environment. Critical aquatic environments where water quality is of prime importance, may be better protected by modification of grazing management towards rotational grazing, and the use of pastures based on grass species other than ryegrass. This provides another management option, along with reduced stocking rates (Field \& Ball 1982), to reduce leaching of nitrate $\mathrm{N}$ into ground water.

\section{ACKNOWLEDGEMENTS}

Mr J. Evans of DSIR Grasslands, Palmerston North, for assistance with field sampling and extraction of nitrate from the samples in the laboratory.

\section{REFERENCES}

Ball, P.R. 1982. Nitrogen balances in intensively managed pasture systems. pp. 47-66. In Nitrogen balances in New Zealand ecosystems. Ed. P.W. Gandar. DSIR, Palmerston North.

Ball, P.R.; Ryden, J.C. 1984. Nitrogen relationships in intensively managed temperate grasslands. Plant and soil 76: 23-33.

Carran, R.A.' 1983. Changes in soil nitrogen during pasture-crop sequences - A review. Proceedings of the Agronomy Society of $\mathrm{New}$ Zealand 13: 29-32.

Denmead, O.T.; Freney, J.R.; Simpson, J.R. 1976. A closed NH, cycle within a plant canopy. Soil biology and biochemistry $8: 161-164$

Field, T.R.O.; Ball, P.R. 1982. Nitrogen balances in an intensively utilised dairy farm system. Proceedings of the $N Z$ G rassland Association 43: 64-69.

Field, T.R.O.; Ball, P.R.; Theobold, P.W. 1985. Leaching of nitrate from sheep-grazed pastures. Proceedings of the NZ G rassland Association 46: 209-214.

Hay, M.J.M.; Brock, J.L.; Thomas, V.J. 1988. Density of Trifolium repens plants in mixed swards under intensive grazing by sheep. Journal of agricultural science, Cambridge 113: 81-86.

Mitchell, K.J. 1957. The influence of nitrogen and moisture supply on the growth of pastures during summer. Empire journal of experimental agriculture 25: 69-78.

Whitehead, D.C. 1970. Carbon, nitrogen, phosphorus and sulphur in herbage plant roots. Journal of the British Grassland Society 25: 236-241. 